\title{
Accelerated decline in lung function in smoking women with airway obstruction: SAPALDIA 2 cohort study
} Sara H Downs*1, Otto Brändli ${ }^{2}$, Jean-Pierre Zellweger ${ }^{3}$, Christian Schindler ${ }^{1}$, Nino Künzli ${ }^{4}$, Margaret W Gerbase ${ }^{5}$, Luc Burdet ${ }^{6}$, Robert Bettschart7, Elisabeth Zemp ${ }^{1}$, Martin Frey ${ }^{8}$, Roland Keller ${ }^{7}$, Jean-Marie Tschopp ${ }^{9}$, Philippe Leuenberger ${ }^{3}$, Ursula Ackermann-Liebrich ${ }^{1}$ and the SAPALDIA team

\begin{abstract}
Address: ${ }^{1}$ Institute of Social and Preventive Medicine, University of Basle, Basle, Switzerland, ${ }^{2}$ Zürcher Höhenklinik, Wald, Switzerland, ${ }^{3}$ Service of Pulmonology, University Hospital Lausanne, CHUV, Switzerland, ${ }^{4}$ Division of Occupational and Environmental Health, University of Southern California, USA, ${ }^{5}$ Division of Pulmonary Medicine, University Hospitals of Geneva, Geneva, Switzerland, ${ }^{6}$ Hôpital intercantonal de la Broye, Payerne, Switzerland, ${ }^{7}$ Hirslanden Klinik Aarau, Switzerland, ${ }^{8}$ Klinik Barmelweid, Aarau, Switzerland and ${ }^{9}$ Centre Valaisan de Pneumologie, Montana, Switzerland

Email: Sara H Downs* - s.downs@unibas.ch; Otto Brändli - otto.braendli@zhw.ch; Jean-Pierre Zellweger - zellwegerjp@swissonline.ch; Christian Schindler - christian.schindler@unibas.ch; Nino Künzli - kuenzli@usc.edu; Margaret W Gerbase - margaret.gerbase@hcuge.ch; Luc Burdet - luc.burdet@hibroye.ch; Robert Bettschart - pneumo@hin.ch; Elisabeth Zemp - elisabeth.zemp@unibas.ch; Martin Frey - martin.frey@barmelweid.ch; Roland Keller - kellermed@swissonline.ch; Jean-Marie Tschopp - elisabeth.voland@admin.vs.ch; Philippe Leuenberger - philippe.leuenberger@chuv.hospvd.ch; Ursula Ackermann-Liebrich - ursula.ackermann-liebrich@unibas.ch

* Corresponding author
\end{abstract}

Published: 26 May 2005

Respiratory Research 2005, 6:45 doi:10.1 186/1465-9921-6-45

This article is available from: http://respiratory-research.com/content/6/1/45

(C) 2005 Downs et al; licensee BioMed Central Ltd.

This is an Open Access article distributed under the terms of the Creative Commons Attribution License (http://creativecommons.org/licenses/by/2.0), which permits unrestricted use, distribution, and reproduction in any medium, provided the original work is properly cited.

\begin{abstract}
Background: The aim was to determine if effects from smoking on lung function measured over Il years differ between men and women.

Methods: In a prospective population based cohort study (Swiss Study on Air Pollution and Lung Diseases in Adults) current smokers in 1991 (18-60 yrs) were reassessed in $2002(\mathrm{n}=1792)$. Multiple linear regression was used to estimate effects from pack-years of cigarettes smoked to $199 \mid$ and mean packs of cigarettes smoked per day between 1991 and 2002 on change in lung volume and flows over the II years.
\end{abstract}

Results: In both sexes, packs smoked between assessments were related to lung function decline but pack-years smoked before 1991 were not. Mean annual decline in $\mathrm{FEV}$, was $-10.4 \mathrm{~mL}(95 \% \mathrm{Cl}$ $15.3,-5.5)$ per pack per day between assessments in men and $-13.8 \mathrm{~mL}(95 \% \mathrm{Cl}-19.5,-8.1)$ in women. Decline per pack per day between I99I and 2002 was lower in women who smoked in 199I but quit before 2002 compared to persistent smokers $(-6.4 \mathrm{vs}-11.6 \mathrm{~mL}, \mathrm{p}=0.05)$ but this was not seen in men $(-14.3 \mathrm{vs}-8.8 \mathrm{~mL} p=0.49)$. Smoking related decline was accelerated in men and women with airway obstruction, particularly in women where decline in FEV , was three fold higher in participants with $\mathrm{FEVI} / \mathrm{FVC}<0.70$ compared to other women $(-39.4 \mathrm{vs}-12.2 \mathrm{~mL} / \mathrm{yr}$ per pack per day, $\mathrm{p}<0.002)$.

Conclusion: There are differences in effects from smoking on lung function between men and women. Lung function recovers faster in women quitters than in men. Women current smokers with airway obstruction experience a greater smoking related decline in lung function than men. 


\section{Background}

Cigarette smoking is the most well known risk factor for accelerating lung function decline in adults [1]. Until recently, smoking prevalence and intensity was greater in men than in women; but there is now evidence that women are starting to smoke as much as men [1,2]. At present, there is no consensus whether women are more sensitive to effects from cigarette smoke than men [1-8]. Relatively few large studies have compared effects from smoking between men and women and results have not been consistent between studies. A greater decline in lung function per pack-year in women compared to men was reported by Chen et al but the converse was found by Xu et al $[5,6]$. Prescott et al reported slightly higher coefficients for decline in $\mathrm{FEV}_{1}$ per pack-year in women compared to men and Connett et al reported similar rates of decline in men and women but a swifter regain in $\mathrm{FEV}_{1}$ in women who quit smoking [4,7].

Smoke related lung damage is characterised by inflammation, airway obstruction and destruction of the lung parenchyma $[9,10]$. Underlying lung characteristics can vary and there is some evidence that smokers differ in their predisposition to develop predominantly emphysema or bronchitis $[11,12]$. Predispositions between men and women may vary because of differences in lung morphology that modify the dispersion and deposition of cigarette smoke or differences in homeostatic processes affecting the efficacy of lung clearance and recovery after smoking cessation [13-15].

The strongest effects from smoking have been consistently measured in current smokers and detrimental effects have been shown to reduce with time from cessation $[1,16]$. The vast majority of surveys of effects from smoking on lung function have focused on $\mathrm{FEV}_{1}$ (forced expiratory volume in one second). However, effects may be also be revealed in other measures of lung function such as $\mathrm{FEF}_{25}$ (forced expiratory flow at $25 \%$ of lung volume) that may better reflect damage to the small airways. An argument for not investigating lung flow rates has been the large inter-subject variability in the rates which prejudices against precise estimation of effects in cross-sectional analyses. In a cohort study however, the inter-participant differences become less important because each subject serves as its own control.

The Swiss Study on Air Pollution and Lung Diseases in Adults (SAPALDIA) is a prospective population based cohort study initiated in 1991 and designed to measure long term effects of air pollution and other risk factors on respiratory health [17]. In cross-sectional analyses, associations were found between levels of lung function and exposure to air pollutants as well as to cigarette smoke [18-20]. Eleven years later, participants have been re- examined using the same methodology. Lung volumes and flows as well as smoking history were measured in 1991 and 2002. The aim of the present analysis is to assess the long term effects from smoking on change in lung function and to compare effects between men and women. The sample examined is current smokers at the time of the first assessment (1991). Effects from smoking up to 1991 and between 1991 and 2002 (SAPALDIA 1 and 2) are compared for lung flows $\left(\mathrm{FEF}_{25}, \mathrm{FEF}_{50}\right.$ and $\mathrm{FEF}_{75}$ ) as well as for $\mathrm{FEV}_{1}$.

\section{Methods}

SAPALDIA is a multi-centre population based prospective cohort study. The study participants were recruited from random population samples from local registries of inhabitants from eight areas of Switzerland. The eight areas were chosen to represent the variety of environmental conditions found in Switzerland concerning geography, climate, degree of urbanisation and air pollution. To meet the selection criteria, individuals had to be 18 to 60 years of age by December 1990, local residents for at least three years and Swiss nationals or foreigners with a residence permit. There were 9651 participants in SAPALDIA 1 representing $60 \%$ of the eligible sample. Participants in SAPALDIA 1 were invited for re-examination between 2001 and 2003. Methods in SAPALDIA have been described in detail $[17,21]$. Ethical approval for the study was given by the Regional Ethics Commission for Clinical Medicine (Swiss Academy of Medical Sciences) and each centres' regional ethics committee.

Identical protocols for spirometry that complied with American Thoracic Society recommendations, were followed in SAPALDIA 1 and 2 [22,23]. The highest values for forced vital capacity (FVC) and $\mathrm{FEV}_{1}$ of an acceptable trial were selected. Measures of expiratory flows $\left(\mathrm{FEF}_{75}\right.$, $\mathrm{FEF}_{50}$ and $\mathrm{FEF}_{25}$ ) were taken from the flow-volume curve with the highest sum of FVC and $\mathrm{FEV}_{1}$. Participants were requested not to use beta-2-agonists or anticholinergic inhalers four hours prior to and long-acting beta agonists, oral beta-2-agonists, theophyline or oral antimuscarinic medication eight hours prior to the time of appointment of the examination.

Information about smoking and other risk factors was gathered through an interview administered questionnaire based on the European Community Respiratory Health Survey (ECRHS) questionnaire [24]. Three categories of smoking status were derived: current smoker, former smoker and never smoker. Smokers had to have smoked more than 20 packs of cigarettes or more than $360 \mathrm{~g}$ of tobacco. 'Current' smokers were smokers who had smoked within the month before the interview. Other participants with validated smoking histories were classified as former smokers. Cumulative cigarette smoking 
exposure was summarised into two variables: pack-years to SAPALDIA 1 based on responses at SAPALDIA 1 and mean packs of cigarettes smoked per day between SAPALDIA 1 and 2 (packs per day) based on responses at SAPALDIA 1 and 2. Pack-years were calculated as years of smoking multiplied by number of cigarettes per day divided by 20 .

Participants were asked not to smoke in the hour before the examination and this was validated in both surveys by measuring carbon monoxide (CO) concentration in exhaled breath using a EC 50 Micro-Smokerlizer Bedfont measuring device.

\section{Statistical analysis}

The effect of smoking on mean annual change in $\mathrm{FEV}_{1}$, $\mathrm{FEF}_{25}, \mathrm{FEF}_{50}$ and $\mathrm{FEF}_{75}$ between surveys was analysed by multiple linear regression. The main covariates investigated were pack-years to SAPALDIA 1 and mean packs per day smoked between surveys. All analyses were confined to subjects classified as current smokers at SAPALDIA 1.

Separate models analyses were conducted for men and women. Covariates tested in the regression models, other than the variables "pack-year" and "packs per day" included study area, atopy, childhood respiratory infection before age five, maternal smoking, paternal smoking, education, current and ever exposure to dust and fumes at work, age at start of smoking, inhaler or not, pipe smoker, solely non-cigarette smoker, body mass index (BMI), weight at baseline, change in weight, change in BMI between surveys and years since quitting. Predictors in each model are shown in the footnote to table 3 . Baseline lung function parameters were included in all models because we could not assume that the change in lung function would be the same for all lung volumes and because we wanted to absorb effects from smoking up to baseline (SAPALDIA 1). However, effects were also reexamined in models that did not contain baseline lung function covariates. For each continuous covariate, we tested whether a linear, quadratic or cubic polynomial best described the relation with change in lung function. Statistical tests for interaction were conducted to determine differences in effects from smoking between men and women and between subjects with $\mathrm{FEV}_{1} / \mathrm{FVC}$ greater or less than 0.70 .

Fourteen men and 11 women were excluded from the regression analyses because they had been classified as current smokers at SAPALDIA 1 and claimed to be never smokers at SAPALDIA 2. Five men and three women were excluded because they claimed to be former smokers at SAPALDIA 2 but had expired CO concentrations greater than 10 ppm (median 15.5, IQR 11.5-20). There were 53 women and 99 men respectively for whom information on pack-years or packs smoked were missing and 74 participants with missing flow data.

Regression diagnostics were conducted to identify influential data. Sensitivity analyses were conducted to examine effects after eliminating points with high leverage or large residuals and to assess possible biases due to missing information about numbers of cigarettes smoked. Analyses were conducted using STATA SE version 8.0 (StataCorp, Texas, 77845 USA).

\section{Results}

Of the 3232 current smokers in 1991 at SAPALDIA 1, 1792 (55\%) participants provided spirometry and smoking information from both surveys (see Table 1). Smokers who did not participate in SAPALDIA 2 had slightly worse lung function at baseline. Male smokers were more likely than women to show evidence of airway obstruction $\left(\mathrm{FEV}_{1} / \mathrm{FVC}\right.$ ratio<0.70) than female smokers and had accumulated more pack-years. The period of follow-up was the same in men and women (median 10.9 years, IQR 10.8-11.0).

Approximately $30 \%$ of men and women who were current smokers in 1991 had quit by 2002. Men had accumulated more pack-years between surveys but were more likely to have quit smoking (see Table 2). Median years since quitting amongst quitters were 5.5 (IQR 2.1 to 9.7) in men and 4.2 (IQR 2.2 to 9.2) in women. The correlation coefficient between pack-years smoked before 1991 and pack-years smoked between surveys was 0.55 in men and 0.68 in women. Mean weight change was $+5.4 \mathrm{~kg}$ in men and $+5.5 \mathrm{~kg}$ in women. Absolute mean declines in lung function were greater in men compared to women except for $\mathrm{FEF}_{25}$. After controlling for mean lung size or flow measured in 1991 differences in change between men and women became less significant except for $\mathrm{FEF}_{25}$. Mean percent change in $\mathrm{FEF}_{25}$ from baseline was -3.4 (5\%CI -3.6, -3.2) in women and -2.8 (95\%CI -3.0, -2.7) in men. The greatest inter-subject variability in change was observed for $\mathrm{FEF}_{75}$ (forced expiratory flow at $75 \%$ of lung volume).

The adjusted effects from pack-years of cigarettes smoked to 1991 and per pack smoked per day per year between 1991 and 2002 are shown in table 3. Removal of baseline lung function variables from models made only small differences to effect estimates. Point estimates for effects from pack-years were stable in all models for both men and women after removal of influential observations.

In men, there was no association between pack-years to 1991 and change in lung function between 1991 and 2002 (see Table 3). The covariate for pack-year was retained as a linear term in all models however, because it 
Table I: Characteristics of current smokers in I99 I (SAPALDIA I)

\begin{tabular}{|c|c|c|c|c|c|c|c|c|}
\hline \multirow{3}{*}{$\begin{array}{l}\text { Characteristic measured in I99I } \\
\text { Median age [yrs] (IQR) }\end{array}$} & \multicolumn{4}{|c|}{ Participants in SAPALDIA I and $2^{*}$} & \multicolumn{4}{|c|}{ Participants only in SAPALDIA I † } \\
\hline & \multicolumn{2}{|c|}{ Men $(n=978)$} & \multicolumn{2}{|c|}{ Women $(n=814)$} & \multicolumn{2}{|c|}{ Men $(n=844)$} & \multicolumn{2}{|c|}{ Women $(n=596)$} \\
\hline & 41.8 & $(32.1,49.6)$ & 38.4 & $(31.0,46.6)$ & 40.2 & $(30.7,49.2)$ & 39.8 & $(30.8,47.3)$ \\
\hline Mean height [cm] (SD) & 175.2 & $(6.8)$ & 163.2 & $(6.6)$ & 174.4 & $(7.2)$ & 163.4 & $(6.5)$ \\
\hline Mean weight [kg] (SD) & 76.7 & $(11.1)$ & 59.6 & $(9.5)$ & 75.4 & $(11.7)$ & 61.8 & $(13.8)$ \\
\hline$\%$ atopic & 23.2 & & 18.4 & & 22.6 & & 22.5 & \\
\hline$\%$ severe respiratory infection as an infant & 6.2 & & 9.5 & & 5.3 & & 6.7 & \\
\hline$\%$ basic schooling only & 13.8 & & 17.7 & & 22.1 & & 22.1 & \\
\hline$\%$ exposed to dust \& fumes at work & 45.5 & & 25.1 & & 48.2 & & 25.2 & \\
\hline$\%$ mother smoked & 13.4 & & 18.3 & & 14.4 & & 22.4 & \\
\hline$\%$ father smoked & 61.3 & & 58.5 & & 63.1 & & 59.9 & \\
\hline Median cig/day (IQR) & 20 & $(14,30)$ & 20 & $(10,20)$ & 20 & $(15,30)$ & 20 & $(10,23)$ \\
\hline Median pack-years (IQR) & 20.6 & $(8.3,36.1)$ & 14.4 & $(6.4,25.0)$ & 21.3 & $(9.1,38.2)$ & 15.9 & $(7.2,26.7)$ \\
\hline$\%$ inhaler & 82.9 & & 88.8 & & 87.9 & & 85.9 & \\
\hline Median age started smoking [yrs] (IQR) & 18 & $(16,20)$ & 18 & $(16,20)$ & 18 & $(16,20)$ & 18 & $(16,20)$ \\
\hline Median carbon monoxide [ppm] (IQR) & 19 & $(9,30)$ & 16 & $(8,28)$ & 24 & $(13,35)$ & 20 & $(10,30)$ \\
\hline Mean FVC [mL] (SD) & 5238 & $(861)$ & 3868 & $(624)$ & 5079 & $(874)$ & 3745 & $(631)$ \\
\hline Mean $\mathrm{FEV}_{1}[\mathrm{~mL}](\mathrm{SD})$ & 4031 & (759) & 3099 & (552) & 3902 & (837) & 2957 & $(575)$ \\
\hline Mean $\mathrm{FEF}_{25}[\mathrm{~mL} / \mathrm{s}]$ (SD) & 1535 & (793) & 1427 & (748) & 1562 & $(87 I)$ & 1325 & (734) \\
\hline Mean $\mathrm{FEF}_{50}[\mathrm{~mL} / \mathrm{s}](\mathrm{SD})$ & 4535 & (1529) & 3807 & $(1127)$ & 4421 & $(1641)$ & 3600 & (1182) \\
\hline Mean $\mathrm{FEF}_{75}[\mathrm{~mL} / \mathrm{s}](\mathrm{SD})$ & 7876 & $(2133)$ & 5816 & (1479) & 7528 & (2370) & 5536 & $(1516)$ \\
\hline$\% \mathrm{FEV}_{\mathrm{l}} / \mathrm{FVC} \leq 0.7$ & 15.9 & & 9.3 & & 19.8 & & 14.1 & \\
\hline
\end{tabular}

*With information on spirometry and smoking

† Includes participants in SAPALDIA 2 who provided information on smoking but no spirometry IQR = inter-quartile range

Table 2: Smoking and lung function measured in 2002 (SAPALDIA 2)

\begin{tabular}{|c|c|c|c|c|c|}
\hline \multirow[b]{2}{*}{$\%$ new former smokers } & & \multicolumn{2}{|c|}{ Men $n=978$} & \multicolumn{2}{|c|}{ Women $n=814$} \\
\hline & & 31.7 & & 27.2 & \\
\hline Median pack-years between I99I and 2002 (IQR) & & 9.0 & $(3.8,13.5)$ & 7.6 & $(4.0,11.0)$ \\
\hline$\%$ inhaler & & 84.7 & & 90.3 & \\
\hline \multicolumn{6}{|l|}{ Mean annual change in: } \\
\hline & $\mathrm{FVC}[\mathrm{mL}](\mathrm{SD})$ & -32.6 & $(48.9)$ & -20.7 & $(35.8)$ \\
\hline & $\mathrm{FEV}_{1}[\mathrm{~mL}](\mathrm{SD})$ & -43.8 & (36.6) & -34.7 & $(27.2)$ \\
\hline & $\mathrm{FEF}_{75}[\mathrm{~mL} / \mathrm{s}](\mathrm{SD})$ & -59.1 & $(167.4)$ & -34.1 & $(121.6)$ \\
\hline & $\mathrm{FEF}_{50}[\mathrm{~mL} / \mathrm{s}](\mathrm{SD})$ & -78.7 & $(90.9)$ & -70.1 & $(71.9)$ \\
\hline & $\mathrm{FEF}_{25}[\mathrm{~mL} / \mathrm{s}](\mathrm{SD})$ & -46.9 & $(47.3)$ & -51.8 & $(45.7)$ \\
\hline
\end{tabular}

influenced effect estimates for packs per day between 1991 and 2002. Restricting models to participants who were current smokers in both surveys made no difference to the effect estimates for pack-years to 1991.

In contrast to men, significant non-linear relations between annual change in lung function and pack-years smoked to 1991 were found in women (see Tables 3, 4 and 5). The polynomial terms were highly significant. A non-linear relation between pack-years and change in $\mathrm{FEF}_{25}$ was also seen in women that was not seen in men.
Lung function decline was strongly associated with packs of cigarettes smoked per day between 1991 and 2002 in both men and women (see Table 3). Point estimates were of a similar magnitude in both sexes with an additional mean annual decline in $\mathrm{FEV}_{1}$ per pack of cigarettes smoked per day of $-10.4 \mathrm{~mL}$ in men and $-13.8 \mathrm{~mL}$ in women. Similar patterns to those seen for FEV1, of stronger effects from recent smoking than from past, were found in the change in flows and especially for $\mathrm{FEF}_{25}$ (forced expiratory flow at $25 \%$ of lung volume). 
Table 3: Mean annual change in lung function per pack-year to I99 I and per pack of cigarettes smoked per day between I99 I and 2002 in women and men

\begin{tabular}{|c|c|c|c|c|c|c|c|}
\hline & \multirow[t]{2}{*}{ Term } & \multicolumn{3}{|c|}{ Annual change per pack-year to 1991} & \multicolumn{3}{|c|}{ Annual change per packs per day between $199 \mid$ and 2002} \\
\hline & & Coef & $95 \% \mathrm{Cl}$ & $P$ value & Coef & $95 \% \mathrm{Cl}$ & $\mathrm{P}$ value \\
\hline \multicolumn{8}{|l|}{$\mathrm{FEV}_{1}[\mathrm{~mL}]$} \\
\hline Men $(n=840)$ & Linear & -0.1 & $-0.2,0.1$ & 0.50 & -10.4 & $-15.3,-5.5$ & $<0.001$ \\
\hline \multirow{3}{*}{ Women $(n=735)$} & Linear & 1.3 & $0.7,2.0$ & $<0.001$ & -13.8 & $-19.5,-8.1$ & $<0.001$ \\
\hline & Quadratic & -0.04 & $-0.06,-0.02$ & $<0.001$ & na & na & na \\
\hline & Cubic & 0.0004 & $\begin{array}{l}0.0002, \\
0.0005\end{array}$ & $<0.001$ & na & na & na \\
\hline \multicolumn{8}{|l|}{$\mathrm{FEF}_{75}[\mathrm{~mL} / \mathrm{s}]$} \\
\hline Men $(n=798)$ & Linear & -0.6 & $-1.4,0.1$ & 0.11 & -35.1 & $-57.5,-12.7$ & 0.002 \\
\hline Women $(n=697)$ & Linear & -0.2 & $-1.0,0.7$ & 0.64 & -18.6 & $-42.7,4.9$ & 0.12 \\
\hline \multicolumn{8}{|l|}{$\mathrm{FEF}_{50}[\mathrm{~mL} / \mathrm{s}]$} \\
\hline Men $(n=825)$ & Linear & -0.2 & $-0.6,0.2$ & 0.31 & -22.4 & $-34.5,-10.3$ & $<0.001$ \\
\hline Women $(n=697)$ & Linear & 0.2 & $-0.3,0.8$ & 0.31 & -31.3 & $-46.1,-16.5$ & $<0.001$ \\
\hline \multicolumn{8}{|l|}{$\mathrm{FEF}_{25}[\mathrm{~mL} / \mathrm{s}]$} \\
\hline Men $(n=823)$ & Linear & -0.05 & $-0.1,0.1$ & 0.59 & -8.9 & $-14.5,-3.4$ & $<0.002$ \\
\hline \multirow[t]{3}{*}{ Women $(n=731)$} & Linear & 1.1 & $0.2,1.9$ & 0.01 & -10.0 & $-17.3,-2.8$ & 0.007 \\
\hline & Quadratic & -0.03 & $-0.6,-0.01$ & 0.01 & na & na & na \\
\hline & Cubic & 0.0003 & $\begin{array}{c}0.00005 \\
0.0005\end{array}$ & 0.006 & na & na & na \\
\hline
\end{tabular}

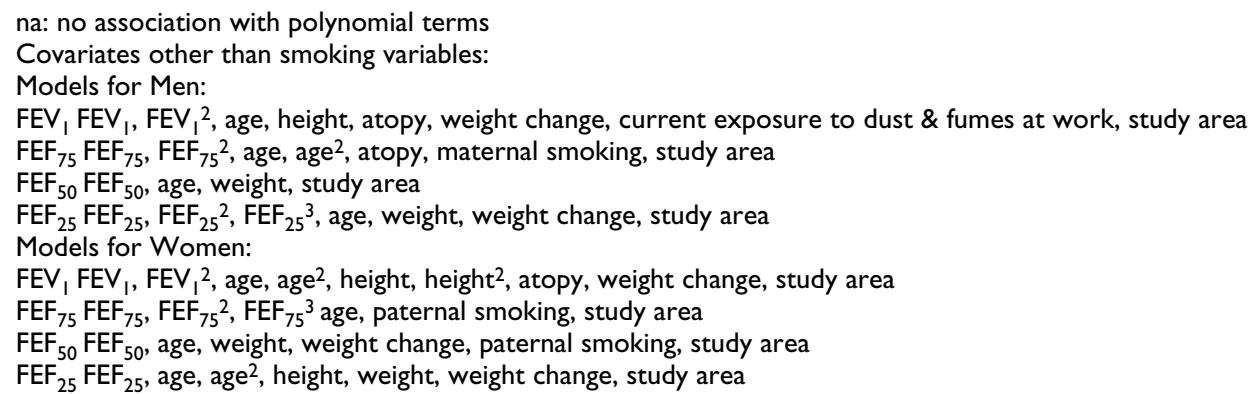

Whereas the decline in $\mathrm{FEV}_{1}$ per pack per day smoked between surveys was smaller in women quitters compared to women continuing smokers; there was no difference in effect estimates for men (see Table 4$)$ ( $p=0.12$ for difference in effect of pack-years in quitters between men and women). Inclusion of a variable for years since quitting into the models for quitters reduced effect estimates for change in FEV1 per pack per day to $-13.4 \mathrm{~mL} / \mathrm{yr}(95 \% \mathrm{CI}$ 1.9 to 2.2 ) in men and $-0.7 \mathrm{~mL} / \mathrm{yr}(-0.6$ to 1.9$)$ in women thereby magnifying the difference in effects between men and women quitters $(p=0.07)$. Difference in effect estimates between women persistent smokers and quitters was also increased by adjusting for years since quitting ( $\mathrm{p}$ $=0.02$ ).

Decline in lung function per pack per day between surveys was greater in men and women with a reduced $\mathrm{FEV}_{1} / \mathrm{FVC}$ at baseline compared to other participants (see Table 5 and Figure 1). The difference in effect per packs per day on annual change in $\mathrm{FEV}_{1}$ between women with and without $\mathrm{FEV}_{1} / \mathrm{FVC}<0.70$ was three fold and highly significant ( $\mathrm{p}<$ 0.002 ). A smaller difference in the effect from cigarette smoking between men with and without $\mathrm{FEV}_{1} / \mathrm{FVC}<0.70$ was seen $(p=0.07)$. The $p$ value for the difference in effects between men and women with a reduced $\mathrm{FEV}_{1}$ / FVC was 0.05 .

\section{Discussion}

Using quantitative information on cigarettes smoked during two time periods, we show similarities and differences in the effect of smoking on lung function decline between men and women. Decline due to smoking is strongly related to recent exposure and to a similar magnitude in men and women overall. However, we found evidence that the facility for recovery from past smoking is greater in women quitters. In both men and women, effects from recent smoking were more detrimental to lung function in individuals with pre-existing airway obstruction. How- 
Table 4: Mean annual change in FEV, per pack-year to I99I and per pack of cigarettes smoked per day between I99 I and 2002 in quitters* and persistent smokers

\begin{tabular}{|c|c|c|c|c|c|c|c|}
\hline & \multirow[t]{2}{*}{ Term } & \multicolumn{3}{|c|}{ Annual change in $\mathrm{mL}$ per pack-year to 1991} & \multicolumn{3}{|c|}{ Annual change in $\mathrm{mL}$ per packs per day between 1991 and 2002} \\
\hline & & Coef & $95 \% \mathrm{Cl}$ & $P$ value & Coef & $95 \% \mathrm{Cl}$ & $P$ value \\
\hline \multicolumn{8}{|l|}{ Quitters $†$} \\
\hline Men $(n=245)$ & Linear & -0.1 & $-0.4,0.3$ & 0.78 & -14.3 & $-22.6,-6.0$ & 0.001 \\
\hline \multirow[t]{3}{*}{ Women $(n=179)$} & Linear & 1.5 & $0.3,2.6$ & 0.01 & -6.4 & $-17.6,4.6$ & 0.25 \\
\hline & Quadratic & -0.04 & $-0.08,-0.01$ & 0.01 & na & na & na \\
\hline & Cubic & 0.0004 & $0.0001,0.0006$ & 0.006 & na & na & na \\
\hline \multicolumn{8}{|l|}{ Persistent smokers $\dagger$} \\
\hline Men $(n=595)$ & Linear & -0.1 & $-0.3,0.12$ & 0.41 & -9.0 & $-15.4,-2.5$ & 0.006 \\
\hline \multirow[t]{3}{*}{ Women $(n=556)$} & Linear & 1.4 & $0.5,2.3$ & 0.001 & -11.6 & $-19.8,-3.5$ & 0.005 \\
\hline & Quadratic & -0.06 & $-0.08,-0.02$ & $<0.001$ & na & na & na \\
\hline & Cubic & 0.0006 & $0.0003,0.0008$ & $<0.001$ & na & na & na \\
\hline
\end{tabular}

*Quitters were current smokers in 1991 who had stopped smoking by 2002.

$\dagger P$ values for interaction between persistent smoking and quitting with packs per day: men $=0.49$ women $=0.05$

na: no association with polynomial terms

Effects estimated from regression models with same covariates as in Table 3

Table 5: Mean annual change in FEV , per pack-year to I99I and per pack of cigarettes smoked per day between $199 \mathrm{I}$ and 2002 by degree of airway obstruction in 1991

\begin{tabular}{|c|c|c|c|c|c|c|c|}
\hline & \multirow[t]{2}{*}{ Term } & \multicolumn{3}{|c|}{ Annual change in $\mathrm{mL}$ per pack-year to I99I } & \multicolumn{3}{|c|}{ Annual change in $\mathrm{mL}$ per packs per day between $199 \mathrm{I}$ and 2002} \\
\hline & & Coef & $95 \% \mathrm{Cl}$ & $\mathrm{P}$ value & Coef & $95 \% \mathrm{Cl}$ & $P$ value \\
\hline \multicolumn{8}{|l|}{$\mathrm{FEVI} / \mathrm{FVC}>0.7 \dagger$} \\
\hline Men $(n=692)$ & Linear & -0.1 & $-0.3,0.1$ & 0.48 & -8.8 & $-14.1,-3.5$ & 0.001 \\
\hline \multirow[t]{3}{*}{ Women $(n=659)$} & Linear & 1.4 & $0.8,2.0$ & $<0.001$ & -12.2 & $-18.1,-6.4$ & $<0.001$ \\
\hline & Quadratic & -0.04 & $-0.06,-0.03$ & $<0.001$ & na & na & na \\
\hline & Cubic & 0.0004 & $0.0002,0.0005$ & $<0.001$ & na & na & na \\
\hline \multicolumn{8}{|l|}{ FEVI/FVC $<0.7 \dagger$} \\
\hline Men $(n=127)$ & Linear & -0.2 & $-0.6,0.2$ & 0.36 & -12.9 & $-25.0,-0.7$ & 0.04 \\
\hline \multirow[t]{2}{*}{ Women $(n=67)$} & Linear & -0.9 & $-2.2,0.5$ & 0.21 & -39.4 & $-69.1,-9.6$ & 0.01 \\
\hline & Quadratic & 0.02 & $0.01,0.04$ & 0.009 & na & na & na \\
\hline
\end{tabular}

† $P$ values for interaction between high and reduced FEVI/FVC with packs per day: men $=0.07$ women $=0.002$

na: no association with polynomial terms

Effects estimated from regression models with same covariates as in Table 3

ever, the strongest effects from smoking were seen in the additional decline in $\mathrm{FEV}_{1}$ in women with a reduced $\mathrm{FEV}_{1} /$ FVC ratio.

The mean unadjusted changes in lung function over the 11-year follow-up of the SAPALDIA cohort study are broadly consistent with changes reported elsewhere $[6,25,26]$. Average annual declines in $\mathrm{FEV}_{1}$ in SAPALDIA were higher than those for smokers in the ECRHS although lower than those reported in the Lung Health Study. Mean annual declines in FEV1 were $-35 \mathrm{~mL}$ in men and $-27 \mathrm{~mL}$ in women persistent smokers in ECRHS but participants were on average younger than the SAPALDIA participants (mean age 34 years versus 40 at study entry). Mean annual declines of $-66 \mathrm{ml}$ and $-54 \mathrm{~mL}$ in $\mathrm{FEV}_{1}$ were reported for men and women continuing smokers respectively in the Lung Health Study (LHS). However, the LHS participants were older (35-60 years versus 18-60 years), had chronic obstructive airways disease and also reported heavier smoking (mean of 30 cigarettes per day versus 20 in SAPALDIA) at study entry [26]. In the Six Cities study, effect estimates for mean annual change in $\mathrm{FEV}_{1}$ per pack smoked in men $(-12.6 \mathrm{ml}$ per pack per day, 95\%CI -9.7, $15.5)$ were similar to the effects we found in men but estimates in women $(-7.2 \mathrm{ml}$ per pack per day, 95\%CI -9.5, 4.8 ) were lower than ours. However, the effects of smok- 
Figure 1. Relation between mean packs per day and annual change in FEV1 in men and women

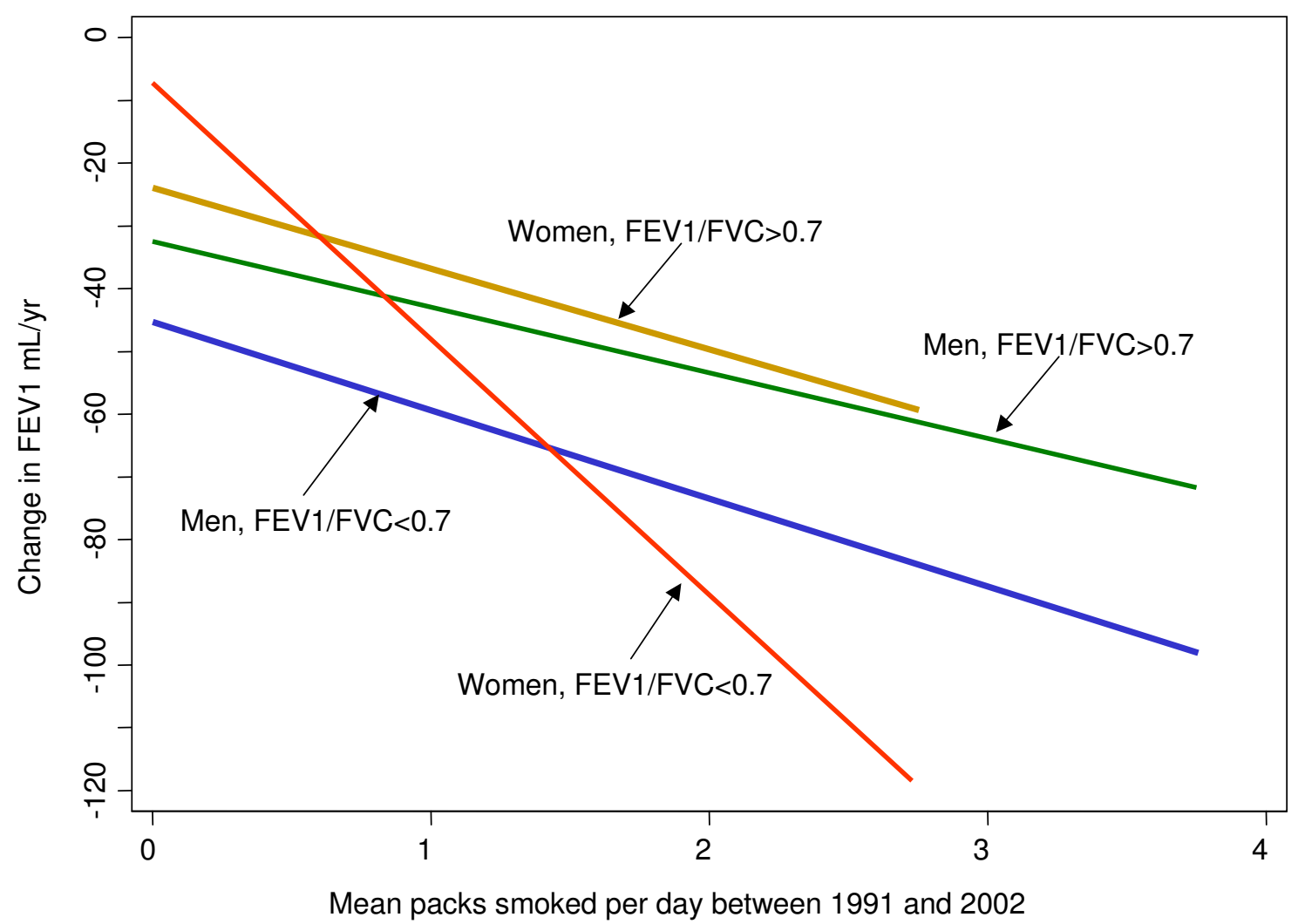

\section{Figure I}

Relation between annual decline in $\mathrm{FEV}_{\mathrm{I}}$ and mean packs/day smoked between 199I and 2002 from regression models reported in Table 3

ing prior to follow-up and smoking during the follow-up period (3-6 years) were summarized into one variable of packs smoked and were not examined separately in the Six Cities study [6].

In both men and women, mean packs smoked per day between 1991 and 2002 were linearly associated with decline in lung function over the time period but packyears to 1991 were not. The point estimates for annual change in lung function per pack per day in the most recent 11 years were similar in men and women with no evidence of airway obstruction. There was some evidence that men and women with poor lung function and who smoked heavily were less likely to participate in the second survey and this may be part of the explanation why we did not measure a negative effect from earlier packyears.

Pack-years of cigarettes smoked before the 1991 were associated with non-linear changes in $\mathrm{FEV}_{1}$ and $\mathrm{FEF}_{25}$ between surveys in women. The polynomial terms were highly significant $(\mathrm{p}<0.001)$ implying multiple testing is unlikely to be an explanation. Possibly women, as a group, have a more heterogeneous response to smoking than men. We found evidence that suggested that women both recover more swiftly after quitting smoking than men but also that women with airway obstruction are more vulnerable to effects from smoking. 
The distribution of years since quitting amongst men and women quitters was similar and relatively short. Previous studies have also reported attenuated effects from smoking after short periods of cessation $[7,27,28]$. In the LHS, the attenuation in lung function decline following smoking cessation could be observed after one year [7]. The significance of the difference in effect from packs smoked per day between women quitters and persistent smokers was marginal ( $\mathrm{p}=0.05)$, but increased with adjustment for years since quitting; consistent with a recovery effect related to quitting. We did not observe an attenuated effect on lung function decline following smoking cessation in men, which has been reported elsewhere $[7,29]$. However, the number of quitters in our study was relatively small and in the Tucson Epidemiological Study of Airways Obstructive Disease, recovery in men was restricted to young men with no evidence of airway obstruction [29]. Our data provide additional evidence that facility for recovery following smoking cessation is, overall, greater in women compared to men.

Reliability of reporting habits may differ between sexes and we are unable to assess the possible extent of this bias in our study. However, we attempted to validate smoking status using expired $\mathrm{CO}$ and similar proportions of men and women were shown to have reported of inconsistent information about smoking habits. In the ECRHS women were as likely as men to report cough and phlegm but significantly less likely to have airflow obstruction [30]. If perception of decline in lung function is greater in women than in men, susceptible women may be more likely to quit smoking than susceptible men.

Evidence for a larger effect from smoking in men with symptoms of obstructive airway disease was presented by Fletcher and Peto almost 30 years ago [31]. Our data showed that both women and men with a reduced $\mathrm{FEV}_{1} /$ FVC experienced an accelerated decline in $\mathrm{FEV}_{1}$ associated with recent cigarette smoking but the effect was significantly greater in women. We are unaware of other studies showing an accelerated effect in lung function decline related to smoking in women with obstructed airways compared to men. However, the female predominance in the Boston Early-Onset COPD Study has been attributed to a higher risk for the development of severe COPD in women compared to men [32]. Men and women persistent smokers in the LHS study have been reported to be approximately equivalent in terms of their percent predicted lung function loss [7]. However, since all LHS participants had evidence of mild to moderate airway obstruction at study entry, we would predict a sex difference in lung function decline per pack of cigarette smoked.
Reduced flow rates are due to a combination of airway narrowing and decreased lung recoil [9]. Predisposition to airway narrowing and decreased lung recoil may vary between men and women given sex differences in lung characteristics [15]. In addition, experimental evidence suggests that the distribution of particle deposition in the airways is likely to be more proximal in women compared to men [14]. Since airway caliber is smaller in women, we could hypothesise that the same reduction in airway diameter would result in a relatively greater impact on the reduction in flow rates in women compared to men [15,33].

An accelerated rate of lung function decline has also been reported amongst asthmatics who smoke [34]. Excluding women with bronchial hyperresponsiveness from our population sample did not reduce the estimates for the effect of packs/day on decline in $\mathrm{FEV}_{1}$ (data not shown). Therefore, although asthmatics may well have experienced an accelerated lung function decline it seems unlikely that asthma per se is an explanation for the different rates of decline between men and women with a reduced $\mathrm{FEV}_{1} / \mathrm{FVC}$. Our findings suggest that smokers with pre-existing airway obstruction are likely to experience accelerated lung function decline irrespective of the potential underlying disease.

\section{Conclusion}

Some of the inconsistent findings from earlier studies comparing effects from smoking on lung function between men and women may be due to difficulties in separating out effects from recent smoking and past smoking. In both men and women recent smoking is a much stronger predictor of lung function decline than smoking more than 10 years previously. Our findings suggest that women recover faster from past smoking than men, but are particularly susceptible to effects from current smoking when they have existing airways obstruction. This observational study over 11 years suggests that women should have even greater incentives, in terms of lung function, to quit smoking than men.

\section{Competing interests}

The author(s) declare that they have no competing interests.

\section{Authors' contributions}

$\mathrm{SD}$ conducted the analyses and drafted the article. $\mathrm{OB}$, JPZ, CS, NK, MG, LB, RB, EZ, MF, RK JMT, UA and PL contributed to the design of the study, the acquisition of data and the interpretation of data. CS also advised on the conduct of the analyses. All authors contributed to the conception of the research question, made important intellectual contributions during the drafting process and have given approval for the final version. 


\section{Acknowledgements}

Research support provided by the National Science Foundation of Switzerland (grant no.3265896.0I), the Federal Office for Forest, Environment and Landscape, the Federal Office of Public Health, the Cantons Basel-Stadt, Basel-Land, Geneva, Zurich, Ticino, Aargau, Luzern, the Swiss Lung League and the Lung League of Ticino and Zurich. N. Künzli is supported by NIEHS P30 ES07048 and the Hastings Foundation.

The study could not have been conducted without the help of the study participants, technical and administrative support and the medical teams and field workers at the local centres and we acknowledge their indispensable contributions.

The SAPALDIA team includes: Ph. Leuenberger ( $p$ ) co-dir, U. AckermannLiebrich (e) co-dir, J.C. Barthélémy (c), A. Bircher (a), K. Blaser (a), G. Bolognini (p), L. Bayer-Oglesby (exp),O. Brändli (p), R. Bettschart (p), M. Brutsche (p), L. Burdet (p), C. Defila (m), S.H. Downs (e/s), D. Felber Dietrich (c), M. Frey (p), J.M. Gaspoz (c), M.W. Gerbase (p), M. Imboden (g), W. Karrer (p), D. Keidel (s), R. Keller (p), P. Städele-Kessler (s), B. Knöpfli (p), B. Kuna-Dibbert (e), N. Künzli (e/exp), U. Meyer (g), A. Morabia (e), U. Neu (exp), L. Nicod (p), A.P. Perruchoud (p), M. Pons (p), N. Probst Hensch (g), E. Russi (p), C. Schindler (s), J. Schwartz (e), F. Schwarz (p), P. Straehl (exp), JM. Tschopp (p), B. Wüthrich (a), JP. Zellweger (p), E. Zemp-Stutz (e) (a) allergology, (c) cardiology, (e) epidemiology, (exp) exposure, (g) genetic \& molecular biology, (p) pneumology, (s) statistics

\section{References}

I. Pauwels RA, Buist AS, Calverley PM, Jenkins CR, Hurd SS: Global strategy for the diagnosis, management, and prevention of chronic obstructive pulmonary disease. NHLBI/WHO Global Initiative for Chronic Obstructive Lung Disease (GOLD) Workshop summary. Am J Respir Crit Care Med 200I, 163:1256-1276.

2. Ulrik CS: Smoking and mortality in women:"smoke like a man, die (at least) like a man". Eur Respir Mon 2003, 25: I03-I I 7.

3. Marang-van de Mheen PJ, Davey Smith G, Hart CL, Hole DJ: Are women more sensitive to smoking than men? Findings from the Renfreww and Paisley study. Int J Epidemiol 200I, 30:787-792.

4. Prescott E, Bjerg AM, Andersen PK, Lange P, Vestbo J: Gender difference in smoking effects on lung function and risk of hospitalization for COPD: results from a Danish longitudinal population study. Eur Respir J 1997, 10:822-827.

5. Chen Y, Horne SL, Dosman JA: Increased susceptibility to lung dysfunction in female smokers. Am Rev Respir Dis 1991, I 43: 1224-1230.

6. Xu X, Dockery DW, Ware JH, Speizer FE, Ferris BGJ: Effects of cigarette smoking on rate of loss of pulmonary function in adults: a longitudinal assessment. Am Rev Respir Dis 1992, 1 46: I 345 - I 348 .

7. Connett JE, Murray RP, Buist AS, Wise RA, Bailey WC, Lindgren PG, Owens GR: Changes in smoking status affect women more than men: results of the lung health study. Am J Epidemiol 2003, I 57:973-979.

8. Vollmer WM, Enright PL, Pedula KL, Speizer F, Kuller LH, Kiley J, Weinmann GG: Race and gender differences in the effects of smoking on lung function. Chest 2000, I I 7:764-772.

9. Brusasco V, Pellegrino R: Functional classification of COPD. Eur Respir Rev 2002, I 2:284-286.

10. Amin K, Ekberg-Jansson A, Lofdahl CG, Venge P: Relationship between inflammatory cells and structural changes in the lungs of asymptomatic and never smokers: a biopsy study. Thorax 2003, 58:135-142.

11. Cosio Piqueras MG, M.G. C: Disease of the airways in chronic obstructive pulmonary disease. Eur Respir J Suppl 200I, 34:4Is-49s.

12. Clark KD, Wardrobe-Wong N, Elliott J], Gill PT, Tait NP, Snashall PD: Patterns of lung disease in a "normal" smoking population: are emphysema and airflow obstruction found together? Chest 200I, I 20:743-747.
13. Anderson PJ, Wilson JD, Hiller FC: Respiratory tract deposition of ultrafine particles in subjects with obstructive or restrictive lung disease. Chest 1990, 97:11115-1 I20.

14. Kim CS, Hu SC: Regional deposition of inhaled particles in human lungs: comparison between men and women. J Appl Physiol 1998, 84: 1834-1844.

15. Becklake MR, Kauffmann F: Gender differences in airway behaviour over the human life span. Thorax 1999, 54:1 II9-1 I 38.

16. Scanlon PD, Connett JE, Waller LA, Altose MD, Bailey WC, Buist AS: Smoking cessation and lung function in mild-to-moderate chronic obstructive pulmonary disease. The Lung Health Study. Am J Respir Crit Care Med 2000, 16 I:381-390.

17. Martin BW, Ackermann-Liebrich U, Leuenberger P, Kunzli N, Stutz EZ, Keller R, Zellweger JP, Wuthrich B, Monn C, Blaser K, Bolognini G, Bongard JP, Brandli O, Braun P, Defila C, Domenighetti G, Grize L, Karrer W, Keller-Wossidlo H, Medici TC, Peeters A, Perruchoud AP, Schindler C, Schoeni MH, Villiger B, et al.: SAPALDIA: methods and participation in the cross-sectional part of the Swiss Study on Air Pollution and Lung Diseases in Adults. Soz Praventivmed 1997, 42:67-84.

18. Ackermann-Liebrich U, Leuenberger P, Schwartz J, Schindler C, Monn C, Bolognini G, Bongard JP, Brandli O, Domenighetti G, Elsasser S, Grize L, Karrer W, Keller R, Keller-Wossidlo H, Kunzli N, Martin BW, Medici TC, Perruchoud AP, Schoni MH, Tschopp JM, Villiger B, Wuthrich $B$, Zellweger JP, Zemp E: Lung function and long term exposure to air pollutants in Switzerland. Study on Air Pollution and Lung Diseases in Adults (SAPALDIA) Team. Am J Respir Crit Care Med 1997, 155:122-129.

19. Schindler C, Kunzli N, Bongard JP, Leuenberger P, Karrer W, Rapp R, Monn C, Ackermann-Liebrich U: Short-term variation in air pollution and in average lung function among never-smokers. The Swiss Study on Air Pollution and Lung Diseases in Adults (SAPALDIA). Am J Respir Crit Care Med 200I, 163:356-36I.

20. Leuenberger $P$, Schwartz J, Ackermann-Liebrich $U$, Blaser K, Bolognini G, Bongard JP, Brandli O, Braun P, Bron C, Brutsche M, et al.: Passive smoking exposure in adults and chronic respiratory symptoms (SAPALDIA Study). Swiss Study on Air Pollution and Lung Diseases in Adults, SAPALDIA Team. Am J Respir Crit Care Med 1994, I 50:1222-1228.

21. Ackermann-Liebrich U, Kuna-Dibbert B, Probst-Hensch NM, Schindler C, Felber Dietrich D, Zemp Stutz E, Bayer-Olgesby L, Baum F, Brändli O, Brutsche M, Downs SH, Keidel D, Gerbase MW, Imboden M, Keller R, Knöpfli B, Künzli N, Nicod L, Pons M, Städele P, Tschopp JM, Zellweger JP, Leuenberger P: Follow-up of the Swiss Cohort study on Air Pollution and Lung Diseases in Adults (SAPALDIA 2) 1991-2003: Methods and characterisation of participants. Soz Praventivmed 2005, In press:.

22. American Thoracic Society: Standardization of spirometry- 1987 update. Am Rev Respir Dis 1987, 136:1285- 298.

23. American Thoracic Society: Standardisation of Spirometry 1994 update. Am J Resp Crit Care Med 1995, I 52: I 107-1 I36.

24. Burney PG, Luczynska C, Chinn S, Jarvis D: The European Community Respiratory Health Survey. Eur Respir J 1994, 7:954-960.

25. Chinn S, Jarvis D, Melotti R, Luczynska C, Ackermann-Liebrich U, Anto J, Cerveri I, de Marco R, Gislasan T, Heinrich J, Janson C, Künzli N, Leynaert B, Neukirch F, Schouten J, Sunyer J, Svannes C, Vermeire $P$, Wjst M, Burney $P$ : Smoking cessation, lung function, and weight gain: a follow-up study. Lancet 2005, 365:1629-1635.

26. Anthonisen NR, Connett JE, Murray RP: Smoking and lung function of Lung Health Study participants after II years. Am J Respir Crit Care Med 2002, 1 66:675-679.

27. Bosse R, Sparrow D, Rose CL, Weiss ST: Longitudinal effect of age and smoking cessation on pulmonary function. Am Rev Respir Dis 198I, I23:378-38I.

28. Lange P, Groth S, Nyboe GJ, Mortensen J, Appleyard M, Jensen G, Schnohr P: Effects of smoking and changes in smoking habits on the decline of FEVI. Eur Respir ] 1989, 2:8| |-8|6.

29. Sherrill DL, Holberg CJ, Enright PL, Lebowitz MD, Burrows B: Longitudinal analysis of the effects of smoking onset and cessation on pulmonary function. Am J Respir Crit Care Med 1994, 149:59I-597.

30. de Marco R, Accordini S, Cerveri I, Corsico A, Sunyer J, Neukirch F, Kunzli N, Leynaert B, Janson C, Gislason T, Vermeire P, Svanes C, Anto JM, Burney P: An international survey of chronic obstructive pulmonary disease in young adults according to GOLD stages. Thorax 2004, 59:120-125. 
31. Fletcher $C$, Peto R: The natural history of chronic airflow obstruction. BrMed J 1977, I:1645-1648.

32. Hersh CP, DeMeo DL, Al-Ansari E, Carey VJ, Reilly JJ, Ginns LC, Silverman EK: Predictors of survival in severe, early onset COPD. Chest 2004, I 26: | 1443-I45I.

33. Mead J: Dysanapsis in normal lungs assessed by the relationship between maximal flow, static recoil, and vital capacity. Am Rev Respir Dis 1980, I 21 :339-342.

34. James AL, Palmer LJ, Kicic E, Maxwell PS, Lagan SE, Ryan GF, Musk AW: Decline in lung function in the Busselton Health Study The Effects of Asthma and Cigarette Smoking. Am J Respir Crit Care Med 2005, I7I:109-1।4.

Publish with Bio Med Central and every scientist can read your work free of charge

"BioMed Central will be the most significant development for disseminating the results of biomedical research in our lifetime. " Sir Paul Nurse, Cancer Research UK

Your research papers will be:

- available free of charge to the entire biomedical community

- peer reviewed and published immediately upon acceptance

- cited in PubMed and archived on PubMed Central

- yours - you keep the copyright

Submit your manuscript here:

http://www.biomedcentral.com/info/publishing_adv.asp
BioMedcentral 